. Treatment resulted in a diminution of symptoms, but had no effect on the renal function or the radiographic appearance of the bones, and she died a year later in oliguric renal failure. The post-mortem findings are described.

We wish to thank the many persons who assisted in the accumulation of the data about this patient, particularly Dr. H. G. Sammons, Dr. W. F. R. Pover, and the late Dr. A. H. Henley. We would also thank Dr. R. D. Blachford for referring the patient, and Professors J. W. Orr and D. H. Collins and Drs. J. Hardwicke and W. Whitelaw for pathological reports.

REFERENCES

Beveridge, B., Vaughan, B. F., and Walters, M. N. I. (1959). J. Fac. Radiol. (Lond.), 10, 197. Crawford, T., Dent, C. E., Lucas, P., Martin, N. H., and
Nassim, J. R. (1954). Lancet, 2. 981.

Davies, D. R., Dent, C. E., and Willcox, A. (1956). Brit. med. J., 2,1133
Fletcher, R. F and Besford, H. (1958), Clin, Sci, 17, 113. - and Brown, P. S. (1959) Ibid., 18, 367.

Fourman, L. P. R. (1960). Calcium Metabolism and the Bone Blackwell, Oxford.

Heaney, R. P., and Whedon, G. D. (1958). J. clin. Endocr., 18 1246 .

Ikkos, D., and Luft, R. (1957). Acta endocr. (Kbh.), 25, 312

Kaye, M., Pritchard, j. E., Halpenny, G. W., and Light, W. (1960). Medicine (Baltimore), 39, 157 .

Lillie, R. D. (1954). Histopathologic Technic and Practical Histochemistry, 2nd ed. Blakiston, New York.

Montgomery, R. D., and Standard, K. L. (1960). J. Bone Jt Surg., $42 \mathrm{~B}, 303$.

Nordin, B. E. C.. and Fraser, R. (1956). Lancet, 1, 823, 826

Perkoff, G. T., Eik-nes, K., Carnes, W. H., and Tyler, F. H. (1960). J. clin. Endocr., 20, 1269.

Rifkind, B. M., Chazan, B. I., and Aitchison, J. D. (1960). Bris med. J., 1, 317 .

Sacker, L. S., and Nordin, B. E. C. (1954). Lancet, 1, 347.

Stanbury, S.'W. (1957). Brit. med. Bull., 13, 57.

Steinberg, A., Schechter, F. R., and Segal, H. I. (1954). J. clin. Endocr., 14. 1519.

Stevenson, C. A., and Watson, A. R. (1957). Amer. J. Roentgenol., 78, 13

Wolf, H. L., and Denko, J. V. (1958). Amer. J. med. Sci., 235

\title{
FATAL MYOCARDIAL SARCOIDOSIS
}

BY

\author{
GHBERT FORBES, M.D., B.Sc., F.R.F.P.S. \\ F.R.C.S.Ed. \\ Reader in Charge
}

ALAN USHER, M.B., B.S. Lecturer

Department of Forensic Medicine, University of Sheffield

\section{[With Special Plate]}

Schaumann $(1914,1917)$ first postulated the modern concept of sarcoidosis as a systemic granuloma, probably infective in origin, presenting a pleomorphic clinical picture according to its sites of attack in the body. In about $80 \%$ of cases the process is self-limiting and the patient recovers. Often the disease is an incidental finding. Death from sarcoidosis most frequently results from heart failure-cor pulmonale usually developing secondary to extensive pulmonary sarcoidosis or its residual fibrosis. More rarely sarcoid is found invading the heart directly and embarrassing its action by massive replacement of heart muscle by non-contractile tissue or by interruption of the conducting mechanism. Occasionally it causes valvulitis (Laroche et al., 1955) or pericarditis (Gilg, 1953).

Since Bernstein et al. (1929) reported finding epicardial sarcoid granulomata in a patient dying of pneumonia, all degrees of cardiac infiltration have been described. Involvement of the heart is to be found in about $20 \%$ of all cases of disseminated sarcoidosis (Freiman, 1948 ; Longcope and Freiman, 1952). In many of these cases the cardiac lesion has remained clinically silent, the patient dying from some other manifestation of the disease or from some unrelated condition (Skavlem and Ritterhoff, 1946 ; Hauser, 1946 ; Spencer and Warren, 1938 ; Longcope, 1941). In a few instances the circulatory disturbance produced by cardiac involvement has proved to be of a transitory nature and recovery has followed (Longcope and Fisher, 1941; Moyer and Ackerman, 1950; Gold and Cantor, 1959). There remains a group of cases where myocardial sarcoidosis has led directly to a fatal issue. Probably the first death of this sort was recorded by Longcope and Fisher in 1941. Adickes et al. (1951) had the distinction of recording the first case of myocardial sarcoidosis to be diagnosed in life and subsequently confirmed at necropsy.

Various associated cardiac arrhythmias have been the subject of several excellent papers (Salveson, 1935;
Riley, 1950 ; Gold and Cantor, 1959 ; Porter, 1960), and the electrocardiographic findings in myocardial sarcoidosis have been described by Leitner (1946), Salveson (1935), McCort et al. (1947), and others. Criteria for the histological diagnosis have been firmly established by Nickerson (1937), Bates and Walsh (1948), and Yesner and Silver (1951).

Since 1941 we have collected from the literature (see Table) 24 cases where myocardial sarcoidosis is considered by us to be the lesion primarily and directly responsible for death. We wish to add to these a case of our own.

\section{Case Report}

A white male steelworker aged 44 first presented as an out-patient complaining of increasing shortness of breath and of backache radiating round to the precordial area. There was no significant previous medical history.

On examination at this time the pulse was 86 per minute and regular, and the blood-pressure was $100 / 60 \mathrm{~mm}$. $\mathrm{Hg}$. The heart was slightly enlarged; there was no audible murmur, but a triple rhythm was heard and there were bilateral basal crepitations. The rest of the examination was negative. A tentative diagnosis of myocardial infarction in early congestive heart failure was made and subsequent electrocardiogram was reported by Dr. R. S. Weetch as follows: "Sinus rhythm, P-R interval $0.22 \mathrm{sec}$. Occasional ventricular extrasystoles, spread of QRS complex indicative of interventricular block. Flattened $T$ waves in the first and second limb leads with a raised S-T segment in lead 3. S-T depressed leads V4-6 and T inverted." This record was highly abnormal, and, although not specifically diagnostic of infarction. it was thought to be compatible with it in view of the history and physical findings. The patient was accordingly admitted to hospital, where his general condition improved but his blood-pressure remained low; he developed right bundle-branch block, and after three weeks he was discharged home.

No clinical records of his progress at home are available, but he is said to have led a careful life and did not again complain of chest or back pain. Fifteen days after his 
discharge he collapsed and died while visiting his place of employment, and his death was the subject of an inquest.

\section{Summary of Post-mortem Findings}

External examination showed no abnormality; the structures of the head and neck were normal. At this stage there was no indication for a special examination of the parotid glands or eyes. Both pleural cavities were dry, and the lungs showed only slight oedema of the upper lobes. A number of firm, enlarged lymph-nodes were present in the mediastinum alongside the lower trachea and about its bifurcation. The heart weighed $20 \frac{1}{2}$ oz. (638 g.). All its chambers were dilated and both ventricular walls grossly thickened. What macroscopically appeared to be a greyish-yellow "fibrosis" extended irregularly throughout the entire ventricular myocardium and into the wall of the right atrium (Special Plate, Fig. 1). The left atrium and the cardiac valves appeared normal. The coronary arteries showed only minımal atheroma. Slight enlargement of the spleen was the only abdominal abnormality. Thus, apart from the heart, mediastinal lymph-nodes, and spleen, the rest of the necropsy was substantially negative.

\section{Histology}

Histological examination of the heart showed the presence of typical sarcoid lesions in all parts of the myocardium. In the left atrium there were only occasional early lesions consisting of a few pallid epithelioid cells ringed by scanty lymphocytes. In the right atrium, ventricles, and septum, however, there was massive replacement of the myocardium by a diffuse irregular fibrosis, containing numerous noncaseating tubercles at all stages of development (Special Plate, Fig. 2). Many giant cells, containing from 30 to 50 nuclei and occasional asteroid inclusion bodies (Special Plate, Fig. 3), were scattered throughout the fibrous tissue, both within the tubercles and outside them. Though the granulomata were observed abutting the coronary vessels, there was no evidence of compression or infiltration. The mediastinal lymph-nodes showed extensive intiltration by young granulomata with minimal fibrosis. In the spleen prolonged search disclosed only three small epithelioid tubercles.

Special stains for amyloid (congo red), bacteria including Bacillus tuberculosis (Gram and Ziehl-Neelsen), and fung (periodic acid-Schiff) were all negative. Reticulin fibres were demonstrated (Gömöri) throughout the tubercles, tending to divide the epithelioid cells into clumps. The remaining organs revealed no histological abnormality.

\section{Discussion}

In the above series no significant racial difference is apparent, but males were affected almost twice as frequently as females. Of the 25 patients, $13(52 \%)$ were in their twenties and $22(88 \%)$ were in the $20-50$ age group. No case is recorded below 20 years of age.

The liability of these patients to sudden death, which constitutes their special interest to the forensic pathologist, is well illustrated here-no fewer than 19 patients $(76 \%)$ eventually died suddenly, and in five instances $(20 \%)$ death was classed as unexpected, there being no known previous symptoms or these were few and apparently inconsequential. Omitting these unexpected deaths from further consideration, the remaining 20 victims all suffered some clinical illness severe enough to warrant their seeking medical attention, and all but one of these 20 showed definite cardiovascular abnormality on clinical examination.

Dyspnoea was found to be a leading symptom, though it must be remembered that associated pulmonary disease was frequently reported at necropsy. Five cases $(25 \%)$ presented with Stokes-Adams syndrome due to varying

Tahle Showing Details of 25 Cases of Myocardial Sarcoidosis

\begin{tabular}{|c|c|c|c|c|c|c|c|c|c|c|c|c|}
\hline \multirow[b]{2}{*}{ Authors } & \multirow[b]{2}{*}{ Race } & \multirow[b]{2}{*}{$\begin{array}{l}\text { Sex } \\
\text { and } \\
\text { Age }\end{array}$} & \multicolumn{4}{|c|}{ History } & \multirow[b]{2}{*}{$\begin{array}{l}\text { Symntoms } \\
\text { (neserintion of } \\
\text { Presentation) }\end{array}$} & \multicolumn{4}{|c|}{ Signs } & \multirow[b]{2}{*}{$\begin{array}{c}\text { Necropsy: } \\
\text { Multiple } \\
\text { Organ } \\
\text { Involve- } \\
\text { ment } \dagger\end{array}$} \\
\hline & & & $\begin{array}{c}\text { History } \\
\text { Suggestive } \\
\text { of Uveo- } \\
\text { parotid } \\
\text { Involve- } \\
\text { ment }\end{array}$ & $\begin{array}{l}\text { nefinite } \\
\text { Clinical } \\
\text { IIIness }\end{array}$ & $\begin{array}{l}\text { Sudden } \\
\text { Death }\end{array}$ & $\begin{array}{l}\text { Unex- } \\
\text { pected } \\
\text { Death }\end{array}$ & & $\begin{array}{l}\text { Cardio- } \\
\text { megaly } \\
\text { in Life }\end{array}$ & $\begin{array}{c}\text { Con- } \\
\text { gestive } \\
\text { Heurt } \\
\text { Failure }\end{array}$ & $\begin{array}{c}\text { Arrhyth- } \\
\text { mias** }\end{array}$ & $\begin{array}{c}\text { Ab- } \\
\text { normal } \\
\text { E.C.G. }\end{array}$ & \\
\hline $\begin{array}{l}\text { Longcope and Fisher } \\
\text { (1941) }\end{array}$ & $\mathbf{N}$ & M 40 & - & - & + & + & None & - & - & - & - & + \\
\hline $\begin{array}{c}\text { Johnsiof and Jason } \\
(1944)\end{array}$ & $\mathbf{N}$ & M 24 & - & + & - & - & Dyspnoea & + & + & + & + & + \\
\hline $\begin{array}{l}\text { Scottl and Mckeown } \\
(1948)\end{array}$ & $\mathbf{N}$ & M 26 & - & - & + & + & $\begin{array}{l}\text { pain round heart } 18 \\
\text { months previnusly }\end{array}$ & - & - & - & - & + \\
\hline $\begin{array}{l}\text { Bates and Warsh (1948) } \\
\text { Ricker and Clark } \\
\text { (1449) }\end{array}$ & $\stackrel{\mathbf{N}}{\mathbf{N}}$ & $\begin{array}{ll}\mathbf{M} & 31 \\
\mathbf{M} & 25\end{array}$ & + & $\stackrel{+}{+}$ & $\stackrel{+}{+}$ & $\overline{-}$ & $\begin{array}{l}\text { Weakness, pain in legs } \\
\text { Dyspnoea, failing vision }\end{array}$ & $\overline{-}$ & $\overline{-}$ & $\bar{t}$ & $\stackrel{+}{+}$ & + \\
\hline Kulka (1950) & $\mathbf{N}$ & F 26 & - & - & + & + & Vone & - & - & - & - & + \\
\hline $\begin{array}{l}\text { Yesner } \\
(1951)\end{array}$ & W & M 51 & - & + & - & - & $\begin{array}{l}\text { Dyspnnea, proeressive } \\
\text { convestive heart failure }\end{array}$ & + & + & + & + & + \\
\hline $\begin{array}{l}\text { Adickes ef al (1951) } \\
\text { Simkins (1951) } \\
\text { Oille et al. (1953) } \ldots\end{array}$ & $\stackrel{\text { N }}{\text { ? }}$ & $\begin{array}{ll}M & 28 \\
F & 50 \\
F & 43\end{array}$ & $\stackrel{+}{ \pm}$ & $\stackrel{+}{+}$ & $\dot{t}$ & $\bar{z}$ & $\begin{array}{l}\text { Dvspnoea } \\
\text { Synconal attacks } \\
\text { Tiredness, " angina," }\end{array}$ & $\stackrel{+}{-}$ & \pm & \pm & 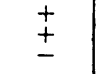 & $\stackrel{+}{+}$ \\
\hline $\begin{array}{l}\text { Gile (1953) } \ldots \\
\text { Sales }(1953) \ldots\end{array}$ & $\underset{\mathbf{N}}{\mathbf{w}}$ & $\begin{array}{ll}\text { M } & 45 \\
\text { M } & 20\end{array}$ & $\overline{+}$ & $\stackrel{+}{+}$ & $\overline{+}$ & $\overline{-}$ & $\begin{array}{l}\text { fehrile } \\
\text { Dvsnnnea } \\
\text { Parnxysmal nocturnal }\end{array}$ & $\stackrel{+}{+}$ & $\stackrel{+}{+}$ & $\overline{-}$ & + & \pm \\
\hline Powell (1954) & $\mathbf{N}$ & P 27 & - & + & - & - & Dysnnnea & + & + & - & + & + \\
\hline Stephën 19ৎ4) $\quad \because$ & $\stackrel{\mathbf{N}}{\mathbf{w}}$ & $\begin{array}{ll}F & 23 \\
M & 47\end{array}$ & $\overline{-}$ & + & $\bar{t}$ & $\bar{z}$ & $\begin{array}{l}\text { Acute dvannnea } \\
\text { nvannnea. chest pain }\end{array}$ & $\overline{-}$ & \pm & \pm & $\dot{t}$ & + \\
\hline $\begin{array}{l}\text { Gottfarb and Wahl- } \\
\text { gren }(19<4)\end{array}$ & $\mathbf{w}$ & F 54 & - & + & + & - & Repeated syncopal at tacks & - & - & + & + & + \\
\hline Cowdeli (1954) $\quad \ldots$ & $\mathbf{w}$ & F 21 & - & - & + & + & ? bilious attack 2 days & - & - & - & - & + \\
\hline $\begin{array}{l}\text { Peacnck ef al. (1957) } \\
\text { Morrisun and Pierce } \\
\text { (1957) }\end{array}$ & $\underset{\mathbf{w}}{\mathbf{w}}$ & $\begin{array}{l}\text { F } 27 \\
\text { M } 33\end{array}$ & $\overline{-}$ & + & + & $\underline{-}$ & $\begin{array}{l}\text { Repeated syncopal attacks } \\
\text { Epigastric pain, vomiting }\end{array}$ & $\bar{t}$ & - & $\begin{array}{l}+ \\
+\end{array}$ & + & + \\
\hline Adams (1958) & w & M 38 & + & + & + & - & Parnxysmal dyspnoea and & - & - & + & + & + \\
\hline Loprete et al. (1958) & $\mathbf{N}$ & M 27 & - & - & + & + & $\begin{array}{l}\text { crannsis } \\
\text { Dysnnnea and chest pain }\end{array}$ & - & - & - & - & + \\
\hline $\begin{array}{l}\text { Poon and Forbus } \\
(1960)\end{array}$ & $\mathbf{w}$ & M 24 & - & + & + & - & Dyspnoea & + & - & + & + & + \\
\hline Poon and Forbus & w & F 40 & - & + & + & - & Cough, syncopal attacks & - & - & + & + & + \\
\hline Porter (1960) & $\mathbf{W}$ & M 21 & + & + & + & - & Svnonpe with grand-mal & - & - & + & + & + \\
\hline Present authors. & $\mathbf{W}$ & M 44 & - & + & + & - & $\begin{array}{l}\text { Dvsnnoea, chest and back } \\
\text { pain }\end{array}$ & + & + & + & + & - \\
\hline
\end{tabular}


degrees of heart-block, and in two cases, our own and that of Stephen (1954), dyspnoea was associated with chest pain so as strongly to mimic myocardial infarction.

On clinical examination cardiac enlargement and some degree of congestive failure were often found. Five patients $(25 \%)$, including our own, had persistent hypotension throughout their illness. Almost three-quarters of this group developed arrhythmias at some stage, and 19 of the 20 were classed as electrocardiographically abnormal. A wide range of E.C.G. abnormalities was reported, but no single abnormality can be said to be diagnostic. There was a wide variation in the degree of cardiac infiltration necessary to cause death. In every case, however, the heart was involved as part of a disseminated process, though in two cases granulomata were discovered in only two other sites in the body. The case reported in this paper is almost unique in that. while the myocardium was so extensively involved, almost no evidence of the presence of the disease was forthcoming from a histological examination of the remaining organs.

\section{Summary}

A case is reported of fatal myocardial sarcoidosis and the literature is briefly reviewed. About one-third of cases of this condition are seen in congestive beart failure, and occasionally the presentation resembles myocardial infarction. Three-quarters of the patients die suddenly-about one-fifth without premonitory symptoms-and at necropy disseminated sarcoidosis is commonly found. In the case reported here the disease was virtually confined to the myocardium and mediastinal lymph-nodes.

It is a pleasure to record our thanks to C. L. Blenkinsop, Esq., H.M. Coroner for the Borough of Rotherham, for permission to puhlish this case; to Dr. R. S. Weetch for details of the clinical history and for the electrocardiographic reports ; and to Mr. R. T. Clegg for technical assistance.

\section{REFERENCES}

Adams, J. L. (1958), Aust, Ann. Med, 7,167

Adickes, G. C., Zimmerman, S. L., and Cardwell, E. S. (1951). Ann. intern. Med., 35, 898

Bates, G. S.. and W.alsh. J. M. (1948). Ibid., 29, 306

Bernstein, M., Konzellman. F. W., and Sidlick, D. M. (1929) Arch. intern. Med.. 44. 721

Cowdell. R. H. (1954). Quart. J. Med., 23, 29

Freiman, D. G. (1948). New Engl. J. Med., 239. 664, 709, 743.

Gilg, I. (1953). Acta derm.-venereol. (Suckh.), 33, 318

Gold. J. A., and Cantor, P. J. (1959). Arch. intern. Med., 104. ioi.

Gnttfarh, G., and Wahlgren, F. (1954). Nord. Med., 52, 985.

Hauser, H. (194h) J (Okla. med. Ass., 39. 395

John

Kulka, W. E. (195(1). Circulation, 1, 772.

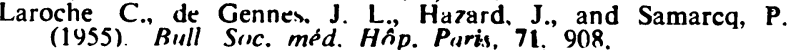

Leitner, St. J. (194h) Cardiologia (Bavel). 10, 379

Longcope. W. T. (1941). J. Amer. med. Ass., 117, 1321

- and Fisher, A. M. (1941). Acta med. scand., 108, 529

- - (1942). ${ }_{j} . M_{1}$ Sinui Hosp. 8.784.

- and Freinuan. D. G. (1952). Medicine (Baltimore), 31, 1.

Loprete, F. P.. Gradone, F., Santoro, T., and Albano, E. H. (1458) Ini. Rec Med." 171. 772.

McCort, J. J.. Wood. R H., Hamilton, J. B.; and Ehrlich, D. E. (1947). Arch imtern. Med., 80, 293.

Morrison. O., and Pierce, W. F. (1957). U.S. armed Forces med. J., 8. 855

Moyer, J H., and Ackerman, A. J. (1950). Amer. Rev. Tuberc., 61. 299

Nickerson, D. A. (1937). Arch. Path., 24. 19.

Oille. W A., Ritchie. R. C., and Barrie, H. J. (1953). Canad. med. Ass. J., 68. 277

Peacock, R A.. Lippschutz, E. J., and Lukas, A. (1957). Circulation. $16 \quad 67$.

Poon, T P.. and Forbus, W. D. (1960). Arch. intern. Med., 104, 771

Porter, G. II. (1960) New Engl. J. Med., 263, 1350

Powell. L. W. (1454). N $C$ med. J., 15. 28 .

Ricker, W., and Clark. M. (1949). Amer. J. clin. Path., 19, 725

Riley, E. A. (1950). Amer. Rev. Tuberc., 62, 231.
Sates, L. M. (1953). J. Fl. med. Ass., 40, 27.

Salveson. H. A. (1935). Acta med. scand.. 86, 127

Schaumann, J. (1914). Sur le lupws pernio. Mémoire présenté en Novembre 1914 à la Société Française de Dermufologie at de Syphiligraphie pour le prix Zambaco. Norstedi, Stockholm. (1917). Ann. Derm. Syph. (Paris), 5, 1.

Scotti, T. M., and McKeown, C. E. (1948). Arch. Path., 46, 289.

Simkins, S. (1951). J. Amer. med. Ass.. 146, 794.

Skavlem, J. H., and Rittenhoff, R. J. (1946). Amer. J. Path., 22, 493.

Spencer, J., and Warren, S. (1938). Arch. intern. Med., 62, 285. Stephen, J. D. (1954). Circulation, 9, 886.

Yesner, R., and Silver, M. (1951). Amer. Heart J., 41, 777.

\section{Preliminary Communications}

\section{Movement of Strontium in the Human Body}

Irradiation of tissue from internally deposited radioactivity may under certain circumstances be the limiting hazard. The occupational hazard to luminizers from radium is a classical example. Irradiation of bone and bone-marrow from struntium-90 in world-wide fall-out is thought to be another. Since strontium-90, unlike radium with its decay products, does not emit $\gamma$-rays, the estimation of the body burden has to be made by indirect means rather than directly with a whole-body counter. Knowledge of the rate of turnover of bone salt and replacement of pre-existing strontium by new strontium (and strontium-90) from the diet is for this purpose essential.

Turnover and Replacement.-In this paper the terms "turnover" and "replacement" are not used interchangeably. For instance, a unit of bone may turn over - that is, be resorbed and re-formed each year. If all the old building blocks are re-utilized the replacement is nil. Only if none of the pre-existing material is re-utilized is the rate of replacement equal to the rate of turnover.

\section{Turnover of Calcium}

Strontium, which has no accepted physiological function, is usually considered together with its chemical analogue, calcium, which is known to be essential for bone and soft tissue.

Bauer et al. (1957) have calculated the rate of turnover of calcium in bone. Their method was to inject radioactive calcium intravenously and to analyse the rate of loss of the radioactive calcium from plasma. An essential requirement of the method is that the marker labels all the calcium fractions of the exchangeable pool uniformly; and this seems to be true for calcium. From the second to tenth day after the injection this loss was exponential, and was attributed to the combined effect of excretion and incorporation into bone. Since the excretion was measured, the rate of incorporation into bone could be calculated as ahour $0.5 \mathrm{~g}$. of calcium per day from an exchangeable pool of abnut $5 \mathrm{~g}$. of calcium. If all the bone so formed were long-lived. this would be equivalent in a standard skeleton containing $1 \mathrm{~kg}$. of calcium to nearly $20 \%$ turnover per year.

Bluhm et al. (1960) noted that the exponential rate of loss of radioactive calcium from plasma hecame slower after about 10 davs. To explain this they postulated that there was additional loss from the exchangeable pool by diffusion into some larger space. so they deduced a rate of turnover about one-half to one-third of that 


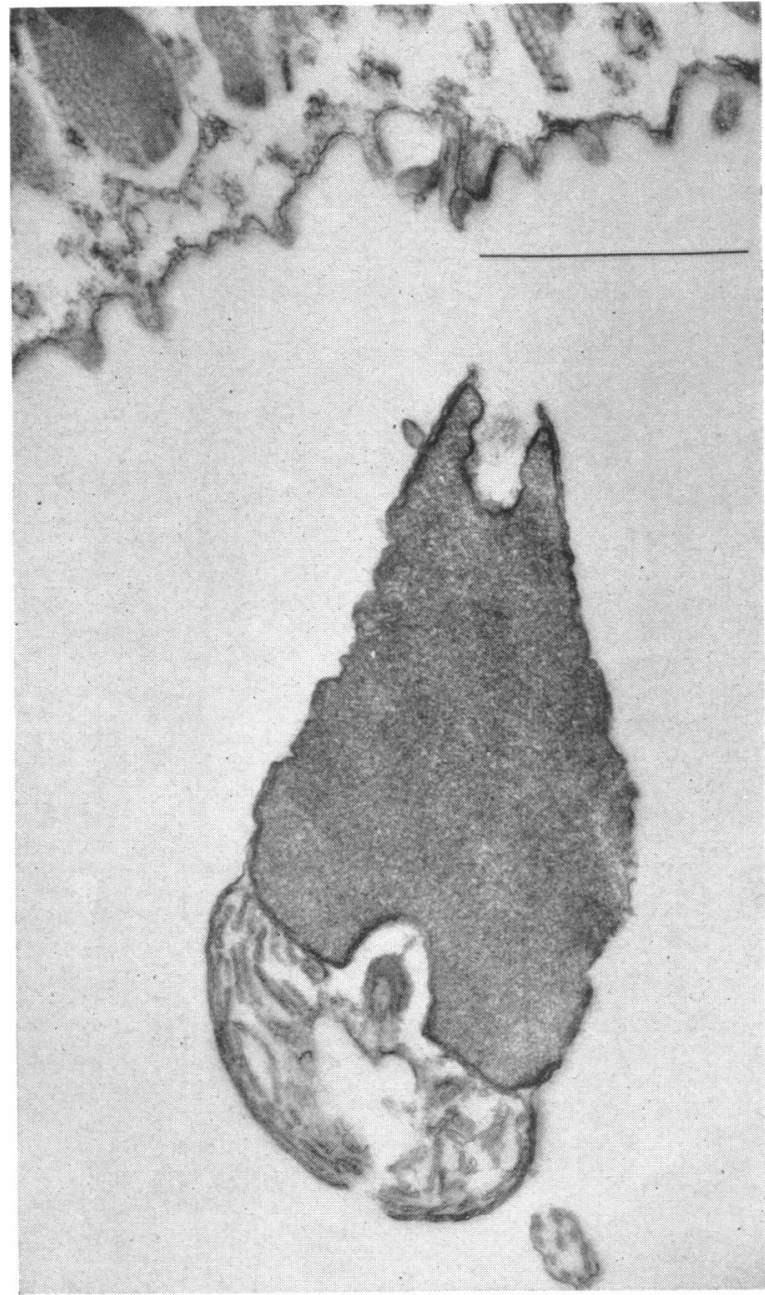

Fig. A.-Electron micrograph of longitudinal section of spermatozoon of Strongylocentrotus droebachiensis (seaurchin) near egg surface of same species. The black line is $1 \mu$ long. (Afzelius and Murray, 1957.)
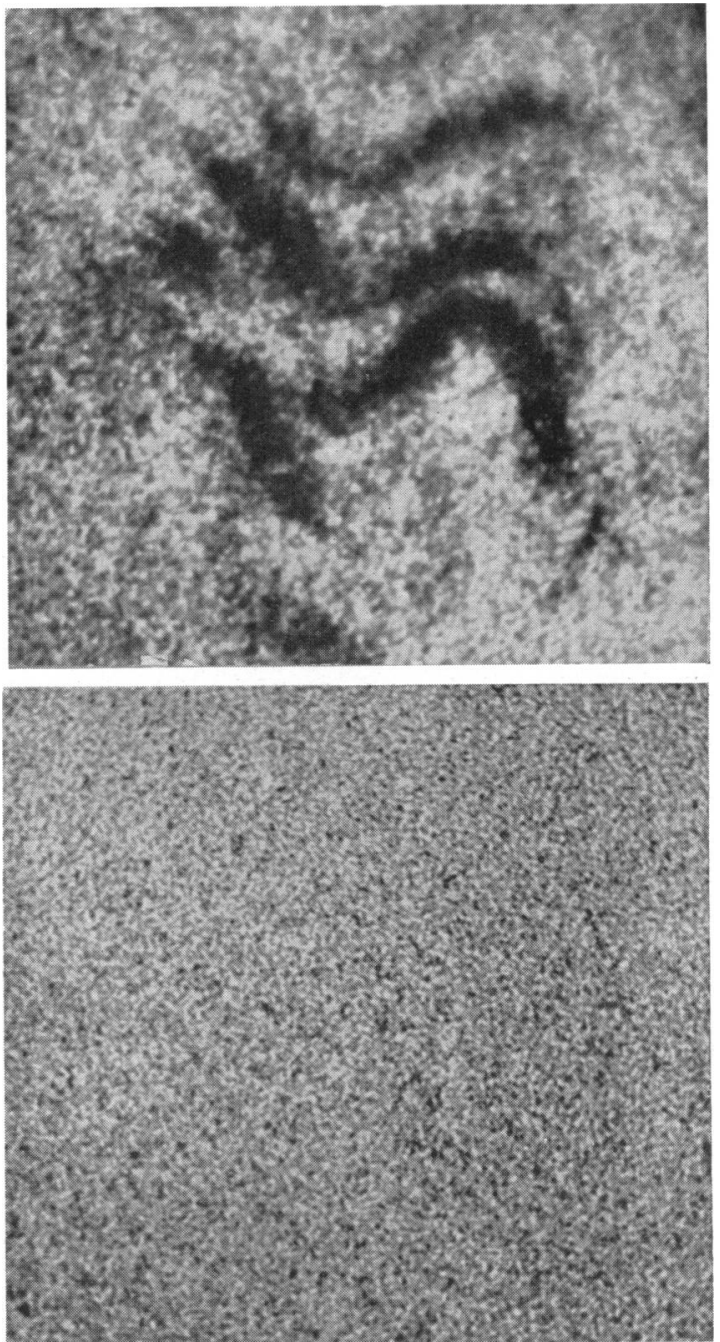

FIG. B.-Low-magnification view of active (top) and dead (bottom) bull spermatozoa in semen.

\section{G. FORBES AND A. USHER: FATAL MYOCARDIAL SARCOIDOSIS}

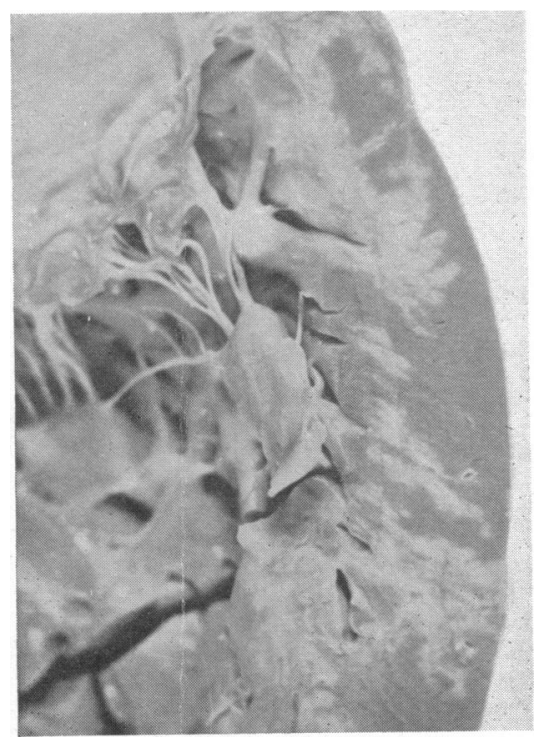

Fic. 1.-Showing granulomatous infiltration of ventricular wall involving papillary muscles.

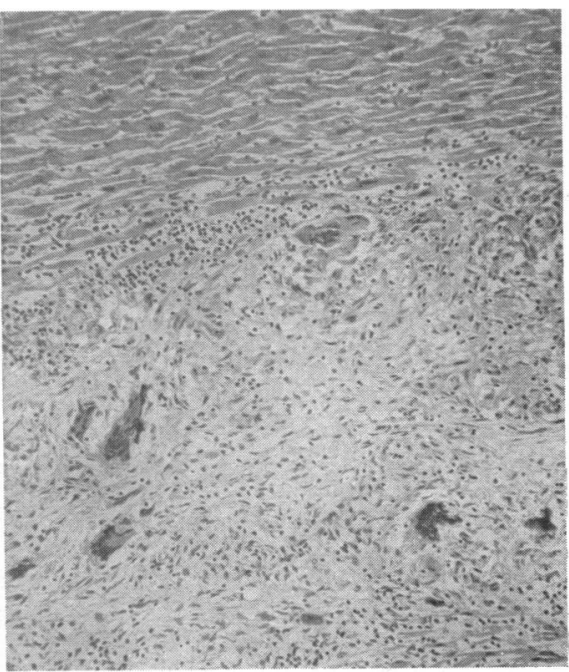

Fig. 2-Medium-power view of a typical field from the interventricular septum. Note the extensive fibrosis with islands of epithelioid cells and numerous multinucleate giant cells. $(\mathrm{H}$. and $\mathrm{E}$. $\times 32$.)

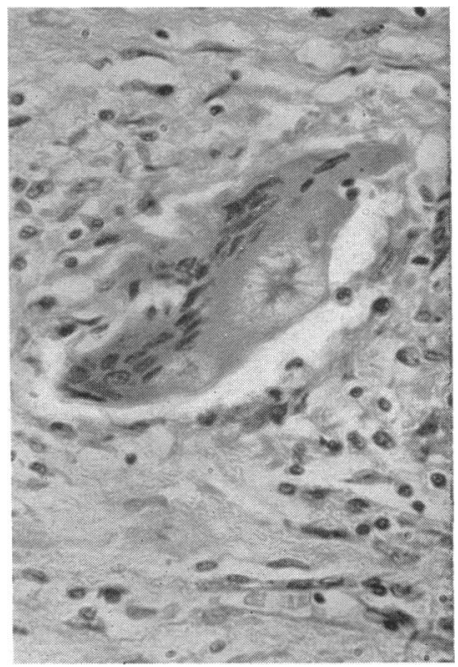

FIg. 3--Multinucleate giant cell containing large asteroid inclusion body. A second smaller asteroid may be seen in the lower part of this cell. (H. and E. $\times 105$.) 